\title{
Nasopharyngeal Carcinoma (NPC) Related Human Leukocyte Antigen (HLA) Haplotype Sharing among Southern East Asian Population
}

\author{
Rika Yuliwulandari, ${ }^{1,2,3}$ Katsushi Tokunaga ${ }^{4}$ \\ ${ }^{1}$ Department of Pharmacology, Faculty of Medicine, ${ }^{2}$ Genomic Medicine Research Group, YARSI Research \\ Institute, YARSI University, Jakarta, Indonesia, ${ }^{3}$ The Indonesian Pharmacogenomics Working Group, \\ ${ }^{4}$ Department of Human Genetics, School of International Health, Graduate School of Medicine, \\ University of Tokyo, Tokyo, Japan
}

\begin{abstract}
The human leukocyte antigens (HLAs) play important roles in the immune systems to response to various pathogens and disease among individuals. The aim of this study was analyze the HLA allele and haplotype frequencies of Southern East Asian population that show high incidence of nasopharyngeal carcinoma (NPC) to evaluate the shared HLA haplotype contribution to NPC susceptibility among the population and analyses the genetic affinities between the population. We collect information of HLA haplotype from our previous study, other published paper, and HLA database in 19 population during 2005 to 2015. Haplotype frequencies were estimated using the maximum likelihood method based on an expectation maximization algorithm with ARLEQUIN v.2.0 software. We also calculated the genetic distance among 19 Southern East Asians based on HLA allele frequency using modified Cavalli-Sforza (DA) distance method. Then, a phylogenetic tree was constructed using DISPAN software and principal component analysis (PCA) was performed using XLSTAT-PRO software. A33-B58-DR3 haplotype, tightly linked to NPC, was commonly observed in all populations, supporting the high incidence of NPC in the populations. In addition, A2-B46 haplotype also associated with NPC, was also commonly found in several population that may also have a role in the disease development. The conclusion is the HLA haplotype sharing has an important role than the HLA allele sharing. The A33-B58-DR3 haplotype and A2-B46-DR9 haplotype in this study could be related to NPC in the Southern East Asian populations. The observed haplotype needs to be tested in the real patients to confirm the assumption.
\end{abstract}

Key words: HLA allele, HLA haplotype, nasopharyngeal carcinoma, Southern East Asian

\section{Penyebaran Haplotipe Human Leukocyte Antigen (HLA) Terkait Nasopharyngeal Carcinoma (NPC) pada Populasi Asia Timur Bagian Selatan}

\begin{abstract}
Abstrak
Human leukocyte antigens (HLAs) berperan penting dalam sistem imun untuk merespons berbagai patogen dan penyakit di antara individu yang berbeda. Tujuan penelitian ini menganalisis frekuensi alel dan haplotipe HLA populasi Southern East Asia yang menunjukkan insidensi yang tinggi terhadap nasopharyngeal carcinoma (NPC) untuk mengevaluasi kerentanan NPC bagi individu. Informasi haplotipe HLA dikumpulkan dari studi sebelumnya, publikasi jurnal internasional, dan database HLA pada 19 populasi dalam periode tahun 2005-2015. Frekuensi haplotipe dihitung menggunakan metode maximum likelihood berdasarkan expectation maximization algorithm menggunakan piranti lunak ARLEQUIN v.2.o. Jarak genetik di antara 19 populasi Southern East Asians dihitung menggunakan metode modified Cavalli-Sforza (DA) distance. Kemudian, pohon filogenetik dikonstruksi dengan metode neighbor-joining (NJ) menggunakan piranti lunak DISPAN. Principal component analysis (PCA) dilakukan menggunakan piranti lunak XLSTAT-PRO. Haplotipe A33-B58-DR3 terkait erat dengan NPC yang biasa terlihat di semua populasi mendukung tingginya insidensi penyakit dalam populasi. Selain itu, haplotipe A2-B46 juga terkait dengan NPC yang juga ditemukan pada beberapa populasi sehingga kemungkinan memiliki peran dalam perkembangan penyakit. Pada kasus NPC, haplotipe HLA lebih berperan dibanding dengan alel HLA. Haplotipe A33-B58-DR3 dan haplotipe A2-B46-DR9 yang ditemukan terkait dengan NPC pada populasi Southern East Asia. Haplotipe yang diamati tersebut perlu diuji pada pasien nyata untuk mengonfirmasi simpulan.
\end{abstract}

Kata kunci: HLA alel, HLA haplotipe, nasopharyngeal carcinoma, Southern East Asia

Korespondensi: Rika Yuliwulandari, M.D., Ph.D. YARSI Research Institute, YARSI University 11th Floor. Jl. Letjen Suprapto Kav. 15, Cempaka Putih, Jakarta Pusat, 10510, Indonesia. E-mail: rika.yuliwulandari@yarsi.ac.id; rika_yuliwulandari@yahoo. co.uk 


\section{Introduction}

The human leukocyte antigens (HLAs) play central roles as antigen-presenting molecules in the immune systems and result in the differences in the response to various pathogens and diseases among individuals such as: bacterial disease (tuberculosis, SARS, Avian influenza, etc.) and viral disease \{HIV, nasopharyngeal carcinoma (NPC)\}. The highly polymorphic HLA molecules also lead to a diversity of allele and haplotype frequencies among various human populations. In general, populations sharing similar patterns of HLA allele distribution are likely to have a relatively close genetic relationship and share the disease distribution pattern. ${ }^{1}$

East Asian population is consistently reported to have two population groups division that are Southern and Northern groups used for studies using various genetic markers such as $\mathrm{Y}$ chromosome, ${ }^{2,3} \mathrm{mtDNA},{ }^{4}$ and HLA..$^{5-7}$ The genetic studies of human diversity in East Asian and the migration routes of ancestral populations also have been investigated, emphasizing the history of East Asian and the North-South differentiation in Chinese population..$^{3,8}$

Southern China and Southeast Asia have been reported to be endemic regions of NPC, one of the most common cancers in Asians but it is rare in Caucasians. ${ }^{9-12}$ The highest prevalence was found in The Guandong Province in South China, with approximately 20 to 40 cases per 100,000 . The previous study also showed the highest incidence (54.7/100,000) were in Cantonese "Boat People". Southeast Asia region showed the intermediate incidence rates of NPC, including Singapore (15/100,000), Malaysia (9.7/100,000), Vietnam (7.5/100,000), Taiwan (7/100,000), and the Philippines $(6.4 / 100,000)$. In Indonesia, NPC incidences estimated at 6.2/100,000 or about 12,000 new cases per year. ${ }^{13}$

One of the strongest and most consistent genetic marker to be associated with the disease risk is HLA as firstly reported by Simons et al. and in recent GWAS study. ${ }^{14}$ HLA-A*02(A*02:07), $\mathrm{A}^{*} 33, \mathrm{~B}^{*} 46$, and $\mathrm{B}^{*} 58$ showed an association with susceptibility to this disease in Chinese of Singapore, Guangdong, and Taiwan. . $^{15,16}$ NPC also has been strictly associated with certain HLA haplotypes: $\mathrm{A}^{*} 02: 07-\mathrm{B}^{*} 46: 01(\mathrm{p}=0.01)$ and $\mathrm{A}^{*}$ 33:03-B*58:01 ( $\left.\mathrm{p}=0.0003\right)$ haplotypes. ${ }^{17}$ The extended haplotype HLA-A*33:03-B* $58: 01 / 2-$ $\mathrm{DRB}_{1}{ }^{*} 03: 01-\mathrm{DQB} 1{ }^{*} 02: 01 / 2-\mathrm{DPB} 1{ }^{*} 04: 01$, was also reported to be significantly associated with increased risk for NPC (OR=2.6, 95\% CI=1.1 to 6.4). ${ }^{18}$ A2-B46-DR9 haplotype was significantly associated with autoimmune thyroid dysfunction in Chinese $(p<0.001)$ that may also has a role in NPC susceptibility. ${ }^{19}$

So far there is no study reporting the shared HLA allele and haplotype among population with high-incidence of NPC. Therefore, study of this issue would be important to understand the genetic share of NPC among those population. In the present report, we evaluate and summarize a nucleotide sequence-level alleles of HLA class I and II loci in nineteen southern groups of East Asian populations. The genetic affinities of those populations and the specific haplotypes associated with nasopharyngeal carcinoma from ten genotypic data-populations are discussed.

\section{Methods}

This study was a retrospective study during a period 2005-2015 and was conducted using 19 southern groups of East Asian population data taken from/gathers by.

The HLA allele frequency at four digit level for HLA-A, -B and -DRB1 were obtained from nineteen populations both from previous studies \{Javanese (Indonesia), ${ }^{7}$ Kihn (Vietnamese), ${ }^{20}$ Han (Yunnan, China), ${ }^{21}$ Maonan (Guangxi, China), ${ }^{22}$ Dai (Yunnan, China), ${ }^{23}$ Hani (China), ${ }^{24}$ Bulang (China), ${ }^{24}$ Jinuo (China), ${ }^{25}$ and Wa (China) $\left.{ }^{25}\right\}$ and from www.allelefrequencies.net \{Malay, Han (Singapore), Thai, Han (Yunnan, China), Jinuo (China), Wa (Yunnan, China), Han (Hong Kong), Han (Guangdong, China), Taiwanese, Han (Fengyuandong, China), Maonan (Guangxi, China), Buyi (China), Nu (China), and Lisu (Yunnan, China)\}. Only populations with minimum sample size of 100 individuals were selected (Fig. 1).

Haplotype frequencies were estimated using the maximum likelihood method based on an expectation maximization algorithm with ARLEQUIN v.2.0 software (available from: http://anthro.unige.ch/arlequin/) with default setting. Genetic distances among 19 southern East Asians populations were calculated by the modified Cavalli-Sforza (DA) distance method. ${ }^{26}$ A phylogenetic tree was constructed by the neighbor-joining (NJ) method using DISPAN software. Principal component analysis (PCA) was performed using XLSTAT-PRO software 
(http://www.xlstat.com).

\section{Results}

The most frequent HLA-A allele in all populations is $A^{*} 11: 01$, except in Javanese (Indonesia) that placed in the second order. Among all selected populations, only Javanese (Indonesia), Malay and Bulang (China) have $\mathrm{A}^{*} 24: 07$ frequency more than $10 \%$. The rest has less than $5 \%$ or even zero presence of $\mathrm{A}^{*} 24: 07$ (Table 1 ).

At the B locus, there was no specific pattern, except $B^{*} 18: 01$ that is more frequent only in Javanese (Indonesia), Thai and Malay than in other southern East Asian populations. Some $B$ alleles that showed frequencies $>10 \%$ were $\mathrm{B}^{*} 40: 01, \mathrm{~B}^{*} 46: 01, \mathrm{~B}^{*} 13: 01, \mathrm{~B}^{*} 15: 02$, and $\mathrm{B}^{*} 15: 13$ in some populations (Table 2).

At the DRB1 locus, DRB1*12:02 was the most frequent in Southeast Asian group and in specific populations live in Southern China, whereas the Taiwanese and southern Han populations exhibit DRB1*09:01 as the most frequent allele. Other DRB1 alleles that shows frequency $>10 \%$ in at least 5 populations were DRB1*09:01, DRB1*15:01, DRB1*15:02, and also DRB1*12:02 (Table 3). Nineteen populations with sequence level allele frequencies were used for the principal component analysis (Fig. 1).

The obtained-DA distances among those populations were used for the phylogenetic tree analysis (Fig. 2). Those two results corresponded well. The southern East Asian populations in fact were also clustered into 2 major groups: the first is the southern Chinese Han populations, including Southeast Asian populations and the second is the specific ethnics live in Southern China (Fig. 3).

The estimated frequencies of haplotypes A33-B58-DR3, A2-B46-DR9, and their shared

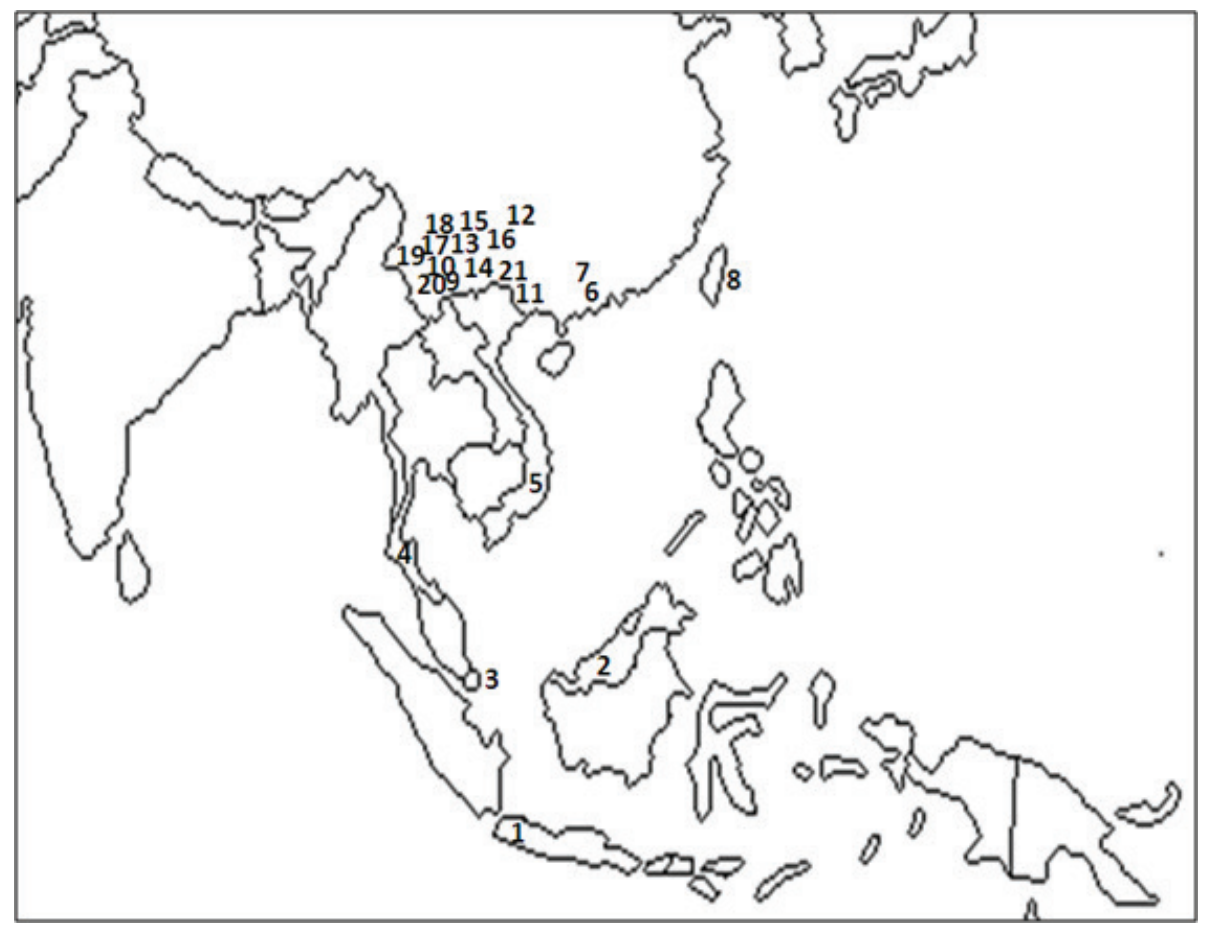

Figure 1 Geographic Distribution of the Areas Resided by 20 Southern East Asian Populations

Legends:

1 Javanese (Indonesia)

2 Malay

3 Han (Singapore)

4 Thai

5 Kihn (Vietnam)

6 Han (Hong Kong)

7 Han (Guangdong, China)
8 Taiwanese

9 Han (Yunnan, China)

10 Han (Fengyuandong, China)

11 Maonan (Guangxi, China)

12 Buyi (China)

13 Dai (Yunnan, China)

14 Bulang (China)
15 Jinuo (China)

16 Hani (China)

17 Wa (Yunnan, China)

$18 \mathrm{Nu}$ (Yunnan, China)

19 Lisu (Yunnan, China) 


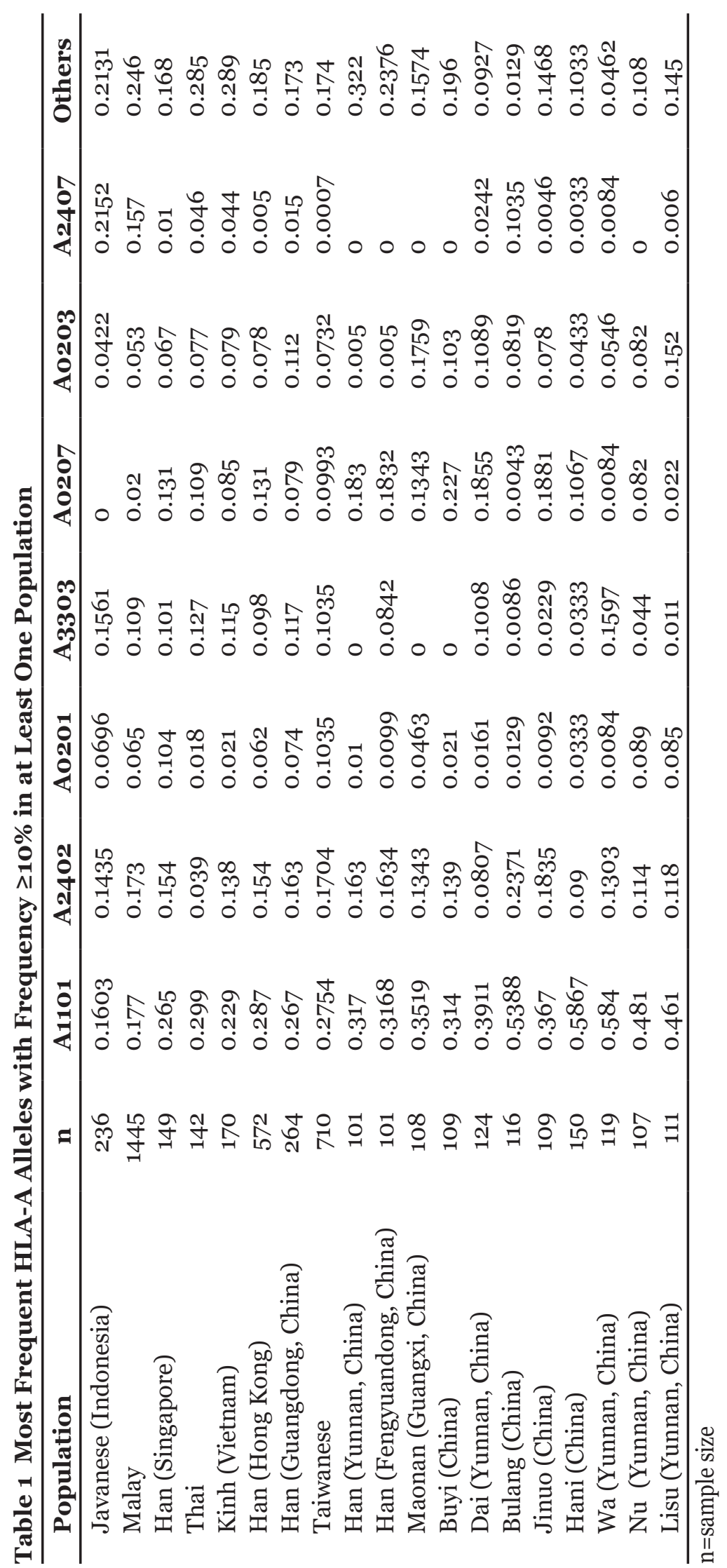




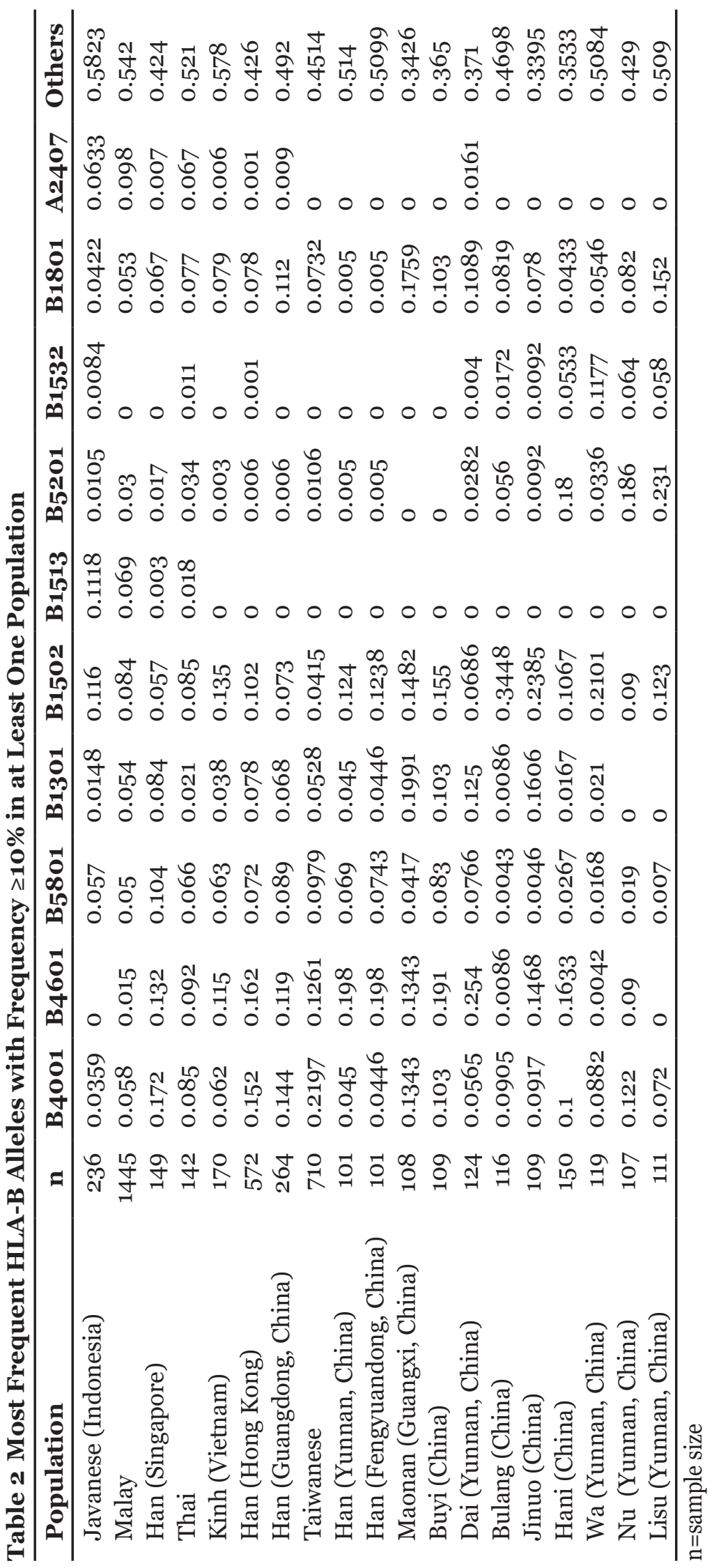




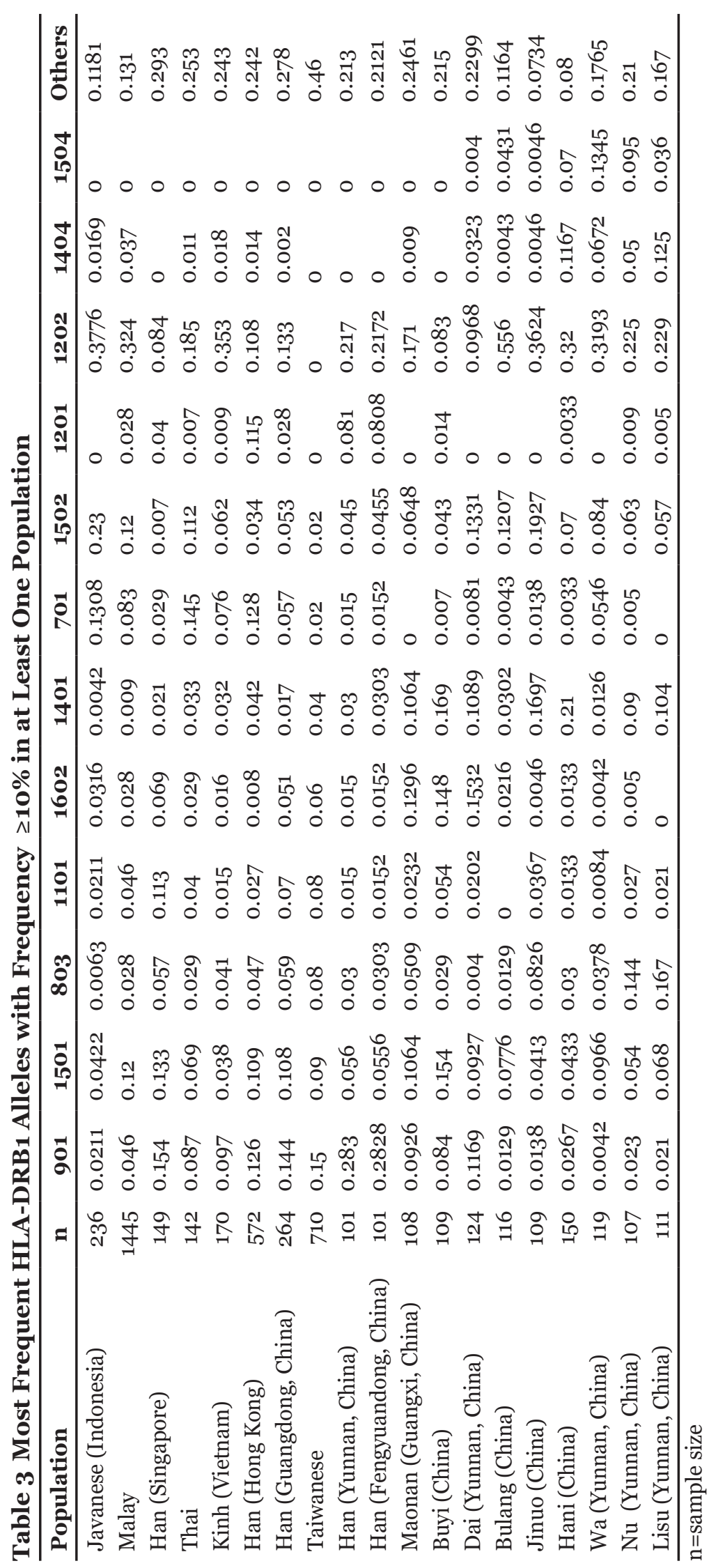




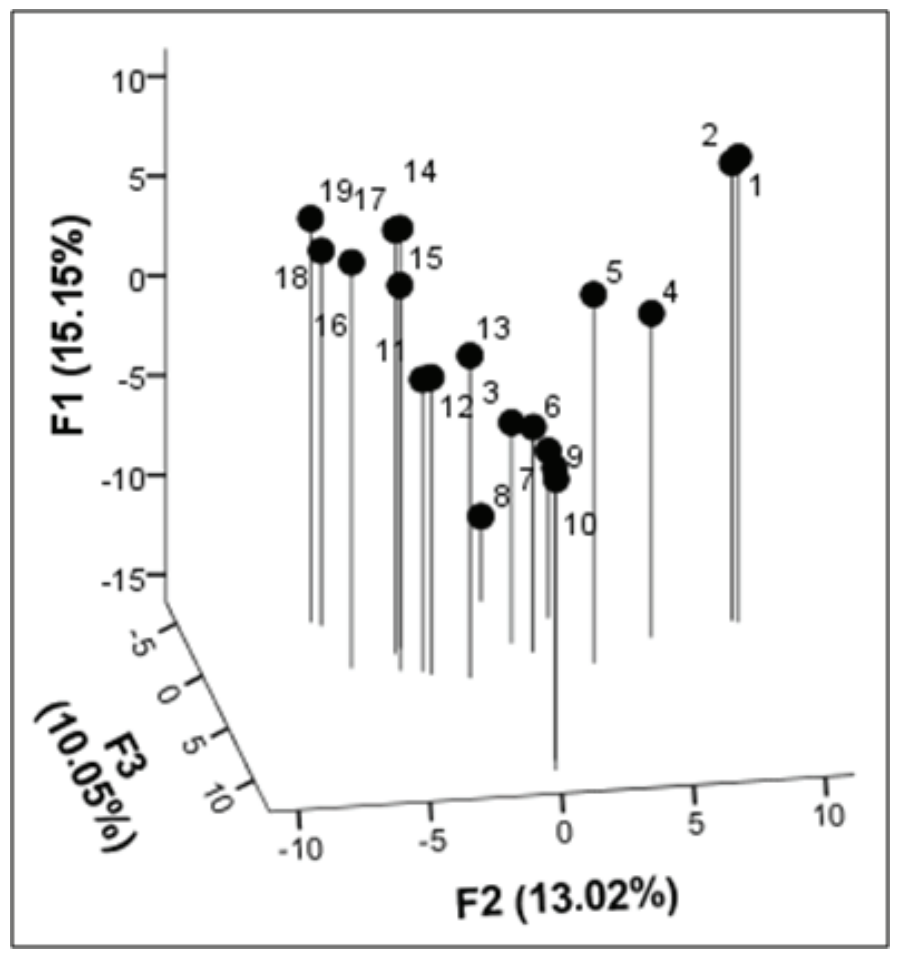

Figure 2 Principal Component Analysis of Southern East Asian Populations (Axis F1, F2, and F3: 38.22\%)

Legends:

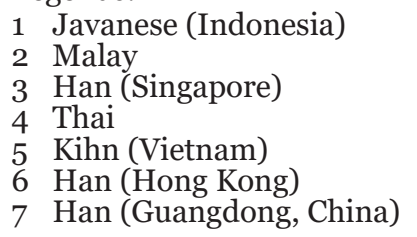

8 Taiwanese

9 Han (Yunnan, China)

10 Han (Fengyuandong, China)

11 Maonan (Guangxi, China)

12 Buyi (China)

13 Dai (Yunnan, China)

14 Bulang (China)
15 Jinuo (China)

16 Hani (China)

17 Wa (Yunnan, China)

$18 \mathrm{Nu}$ (Yunnan, China)

19 Lisu (Yunnan, China) derivative haplotypes are listed in Table 4. The minor haplotypes were presented by the single B allele. Haplotypes A33-B58-DR3 was most frequently observed in Maonan and Dai. Haplotypes A2-B46-DR9/DR14 was commonly observed in Maonan, Dai, Jinuo, and Hani.

\section{Discussion}

Populations with close genetic affinity generally show similar HLA alleles and also haplotype frequencies that may related to HLA related disease distribution. In this study we analyzed and summarized a nucleotide sequence-level alleles of HLA class I and II loci in nineteen southern groups of East Asian populations and the genetic affinities of those populations and see the distribution of the specific haplotypes associated with nasopharyngeal carcinoma from 10 available genotypic data-populations. The pattern of HLA class I and II allele distribution among Southern East Asian may also be relevant to the disease distribution in the regions. HLA genes has been most extensively studied to be associated with NPC. It is postulated that individuals who carry particular HLA alleles might be at an increased risk for susceptibility or protection to NPC. It is because particular HLA molecule may increase or decrease the ability to present EBV antigens to the immune system.

In this study, based on the allele frequencies, the most frequent HLA-A allele in all populations is $\mathrm{A}^{*} 11: 01$, except in Javanese (Indonesia) that placed in the second order. This allele has been reported to be associated with a reduced risk for NPC in Southern Chinese descent. ${ }^{14}$ Populations with Southern Chinese descent used in this study were Javanese (Indonesia), Malay, Han (Singapore), Thai, Kihn (Vietnam), Han (Hong Kong), Han (Guangdong, China), Taiwanese, 


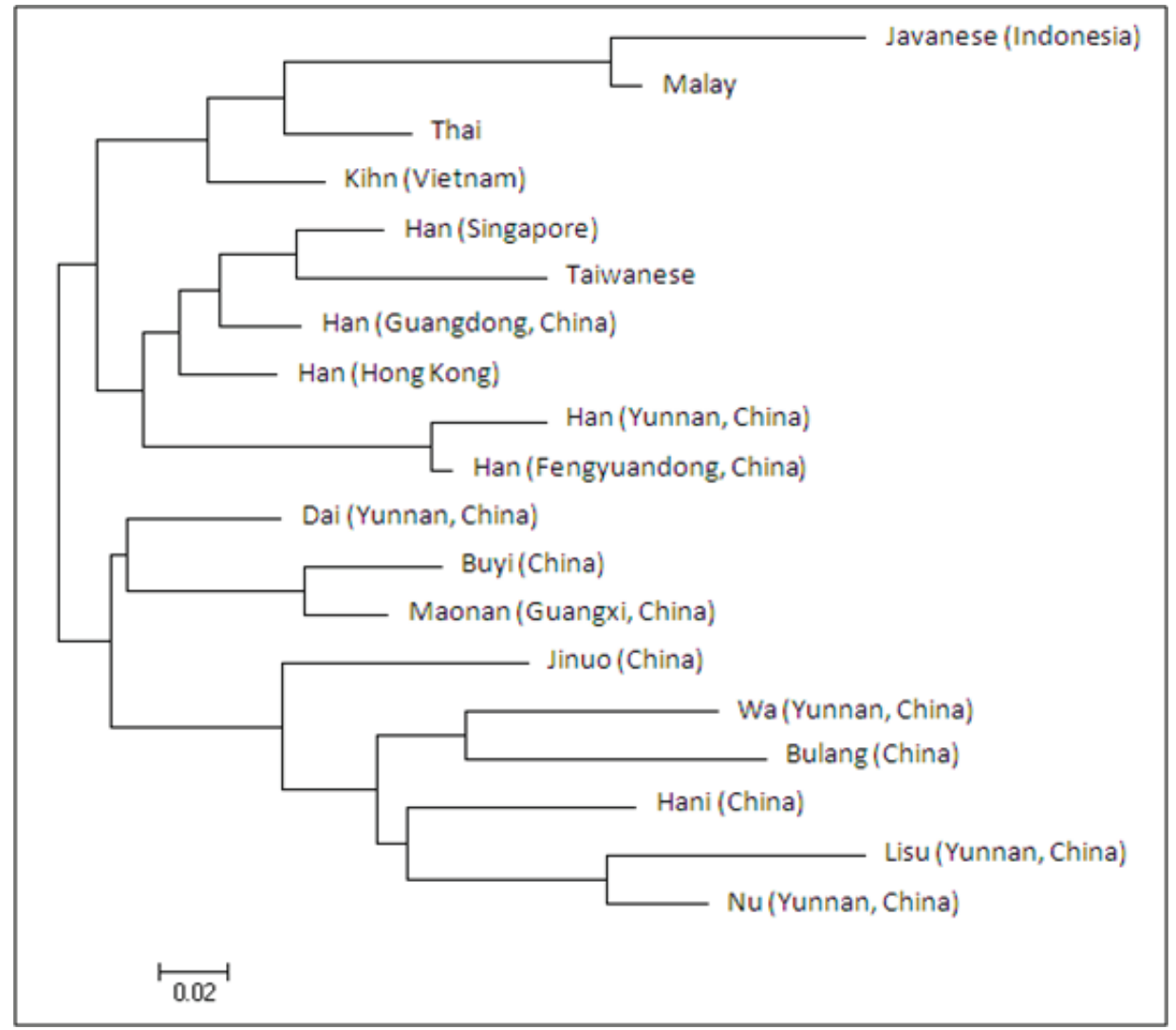

Figure 3 Phylogenetic Tree Analysis of Southern East Asian Populations

Legends:

- Southeast Asian populations: Javanese (Indonesia), Malay, Thai, Khin (Vietnam)

- Southern Han populations: Han (Singapore), Taiwanese, Han (Guangdong, China), Han (Hong Kong), Han (Yunnan, China), Han (Fengyuandong, China)

- Specific populations live in Southern China: Dai (Yunnan, China), Buyi (China), Maonan (Guangxi, China), Jinuo (China), Wa (Yunnan, China), Bulang (China), Hani (China), Lisu (Yunnan, China), Nu (Yunnan, China)

Han (Yunnan, China), Han (Fengyuandong, China), Maonan (Guanxi, China), Buyi (China), Dai (Yunnan, China), Bulang (China), Jinuo (China), Hani (China), Wa (Yunnan, China), Nu (Yunnan, China), Lisu (Yunnan, China), and Naxi (Yunnan, China).

At the $\mathrm{B}$ locus among the most frequent alleles (-B*40:01, $B^{*} 46: 01, B^{*} 13: 01, B^{*} 15: 02$, and $B^{*} 15: 13$ ), only HLA-B*46:01 that has been commonly reported to be associated with NPC in Chinese descendent populations. ${ }^{14}$ The other HLA-B were reported to be associated with other diseases, but only reported in a few population. HLA-B*15:02 has been commonly associated with Carbamazepine induced severe adverse drug reaction in Southern China population group. ${ }^{27}$ HLA-B ${ }^{*} 13: 01$ has been associated with the development of dapsone hypersensitivity syndrom in patients with leprosy in the Chinese population. ${ }^{28}$ It was also reported to be associated with salazosulfapyridine-induce drug rashes with eosinophilia and systemic symptomps in Chinese Han population. ${ }^{29}$ Studied in Thailand showed that HLA-B*40:01 has been associated with stavudine-associated lipodystrophy in HIVinfected patient. ${ }^{30}$

Among the most frequent DRB1 alleles (DRB1*09:01, DRB1*15:01, DRB1*15:02, and DRB1*12:02), none is reported to be associated with NPC. The disease associated with those most frequent DRB1 alleles are systemic lupus erythematosus and rhematoid arthritis in Japanese Population, ${ }^{31}$ grave disease in Chinese Han population in Taiwan, ${ }^{32}$ coronary artery disease in shouthern Han Chinese ${ }^{33}$ and systemic sclerosis, which is autoantibody disease, in Chinese. ${ }^{34}$

In the principle component analysis, two 
Table 4 Estimated Frequencies of A33-B58-DR3, A2-B46-DR9, and Their Derivative Haplotypes

\begin{tabular}{|c|c|c|c|c|c|c|c|c|c|}
\hline \multirow{2}{*}{ Population } & \multirow{2}{*}{$\begin{array}{l}\text { Sample } \\
\text { Size }\end{array}$} & \multicolumn{4}{|c|}{ A33/Others-B58-DR3/Others } & \multicolumn{4}{|c|}{ A2/Others-B46-DR9/14/Others } \\
\hline & & A & B & DR & Freq. & A & B & DR & Freq. \\
\hline $\begin{array}{l}\text { Javanese } \\
\text { (Indonesia) }\end{array}$ & 236 & $\begin{array}{c}33 \\
33 \\
\text { Others }\end{array}$ & $\begin{array}{l}58 \\
58 \\
58\end{array}$ & $\begin{array}{c}3 \\
\text { Others } \\
\text { Others }\end{array}$ & $\begin{array}{l}0.021 \\
0.029 \\
0.006\end{array}$ & & & & \\
\hline Kihn (Vietnam) & 170 & $\begin{array}{c}33 \\
\text { Others }\end{array}$ & $\begin{array}{l}58 \\
58\end{array}$ & $\begin{array}{c}3 \\
\text { Others }\end{array}$ & $\begin{array}{l}0.038 \\
0.027\end{array}$ & $\begin{array}{c}2 \\
2 \\
\text { Others }\end{array}$ & $\begin{array}{l}46 \\
46 \\
46\end{array}$ & $\begin{array}{c}9 \\
\text { Others } \\
\text { Others }\end{array}$ & $\begin{array}{l}0.031 \\
0.036 \\
0.047\end{array}$ \\
\hline $\begin{array}{l}\text { Han (Yunnan, } \\
\text { China) }\end{array}$ & 101 & $\begin{array}{c}33 \\
\text { Others }\end{array}$ & $\begin{array}{l}58 \\
58\end{array}$ & $\begin{array}{l}\text { Others } \\
\text { Others }\end{array}$ & $\begin{array}{l}0.041 \\
0.018\end{array}$ & $\begin{array}{c}2 \\
\text { Others }\end{array}$ & $\begin{array}{l}46 \\
46\end{array}$ & $\begin{array}{l}\text { Others } \\
\text { Others }\end{array}$ & $\begin{array}{l}0.036 \\
0.141\end{array}$ \\
\hline $\begin{array}{l}\text { Maonan (Guangxi, } \\
\text { China) }\end{array}$ & 108 & $\begin{array}{c}33 \\
\text { Others }\end{array}$ & $\begin{array}{l}58 \\
58\end{array}$ & $\begin{array}{l}3 \\
\text { Others }\end{array}$ & $\begin{array}{l}0.036 \\
0.005\end{array}$ & $\begin{array}{l}2 \\
2 \\
2\end{array}$ & $\begin{array}{l}46 \\
46 \\
46\end{array}$ & $\begin{array}{c}9 \\
14 \\
\text { Others }\end{array}$ & $\begin{array}{l}0.045 \\
0.051 \\
0.039\end{array}$ \\
\hline $\begin{array}{l}\text { Dai (Yunnan, } \\
\text { China) }\end{array}$ & 124 & $\begin{array}{l}33 \\
33\end{array}$ & $\begin{array}{l}58 \\
58\end{array}$ & $\begin{array}{c}3 \\
\text { Others }\end{array}$ & $\begin{array}{l}0.044 \\
0.032\end{array}$ & $\begin{array}{c}2 \\
2 \\
2 \\
\text { Others }\end{array}$ & $\begin{array}{l}46 \\
46 \\
46 \\
46\end{array}$ & $\begin{array}{c}9 \\
14 \\
\text { Others } \\
\text { Others }\end{array}$ & $\begin{array}{l}0.071 \\
0.069 \\
0.049 \\
0.065\end{array}$ \\
\hline Bulang (China) & 116 & Others & 58 & Others & 0.004 & Others & 46 & Others & 0.008 \\
\hline Jinuo (China) & 109 & Others & 58 & Others & 0.005 & $\begin{array}{l}2 \\
2\end{array}$ & $\begin{array}{l}46 \\
46\end{array}$ & $\begin{array}{c}14 \\
\text { Others }\end{array}$ & $\begin{array}{l}0.063 \\
0.083\end{array}$ \\
\hline Hani (China) & 150 & 33 & 58 & Others & 0.027 & $\begin{array}{c}2 \\
2 \\
\text { Others }\end{array}$ & $\begin{array}{l}46 \\
46 \\
46\end{array}$ & $\begin{array}{c}14 \\
\text { Others } \\
\text { Others }\end{array}$ & $\begin{array}{c}0.064 \\
0.019 \\
0.08\end{array}$ \\
\hline $\begin{array}{l}\text { Wa (Yunnan, } \\
\text { China) }\end{array}$ & 119 & 33 & 58 & 3 & 0.017 & Others & 46 & Others & 0.004 \\
\hline $\begin{array}{l}\text { Naxi (Yunnan, } \\
\text { China) }\end{array}$ & 75 & Others & 58 & Others & 0.007 & $\begin{array}{c}2 \\
\text { Others }\end{array}$ & $\begin{array}{l}46 \\
46\end{array}$ & $\begin{array}{l}\text { Others } \\
\text { Others }\end{array}$ & $\begin{array}{c}0.04 \\
0.026\end{array}$ \\
\hline
\end{tabular}

Freq: Estimated haplotype frequency

clusters were observed. It may also reflect the migration history of Southern East Asian populations, regardless the north-to-south or south-to-north migration route theory. Southeast Asian populations are closer to Southern Han Chinese populations than to the specific ethnics live in Southern China. A study in Indonesia by Yuliwulandari et al. (2008)7 reinforces the PCA result in this study.

At the haplotype level, haplotype A35-B58$\mathrm{DR}_{3}$, reportedly to be strictly associated with NPC. ${ }^{18,20}$ This haplotype is commonly found among general population. With those regard, the estimated frequencies of this haplotype in different populations using the maximum likelihood method are reliable for presuming the susceptibility to the disease in each population in Southern East Asia. B58 carrying haplotypes predominantly include specific alleles, A33 and DR3. Thus, the haplotype containing B58 may have been well conserved. However, it should be understood that if NPC is associated with variant haplotypes derived from the A35B58-DR3 haplotype, further family studies to discribe more precise di-haploidy information are needed to define susceptibility gene(s). The minor haplotypes were presented by the single B allele, considering that inferring haplotype using maximum likelihood method is not reliable for those infrequent haplotypes. Dai and Maonan populations carried both haplotypes..$^{22,23}$

Haplotype A2-B46-DR9, which has been found to be associated with autoimmune thyroid dysfunction in Chinese was less frequent in all southern East Asian populations. ${ }^{19}$ B46 is also frequently linked to DR14, such as in Jinuo (China) ( $\mathrm{f}=0.063$ ), Maonan (Guangxi, China) $(\mathrm{f}=0.051)$, Dai (Yunnan, China) $(\mathrm{f}=0.069)$. Other less frequent derivative haplotypes containing B46 were also frequently observed. Thus, B46 
haplotypes have been relatively more diversified than B58 haplotypes. Considering that A2-B46 was also frequently linked to both DR14 and DR9, it is possible that A2-B46-DR14 may also be related to NPC in this southern East Asian population group. Further study is needed to confirm this assumption. The limitation of this study were that we did not analyze the role of the HLA haplotype directly in NPC patients in Indonesia, in which Indonesia showed the intermediate incidence rates of NPC. ${ }^{13}$ Therefore in the future we need to apply the result of this study in the population to screen NPC in Indonesia population.

\section{Conclusion}

HLA allele(s) and haplotype distribution shows the closeness of genetic relationship among populations. Those distributions tend to affect disease distribution in the population, including NPC. In NPC, HLA haplotype sharing is more important than HLA allele sharing. The A33B58-DR3 haplotype and A2-B46-DR9 haplotype in this study could be related to NPC, especially in the Southern East Asian populations group. The observed haplotype needs to be tested in the real patients to confirm the susceptibility of the haplotype in Indonesia.

\section{Conflict of Interest}

The authors declare no conflict of interests.

\section{Acknowledgement}

We would like to thank the late Prof. Malcolm Simons for useful discussion and Ms. Kinasih Prayuni for editing the manuscript.

\section{References}

1. Shiina T, Hosomichi K, Inoko H, Kulski JK. The HLA genomic loci map: expression, interaction, diversity and disease. J Hum Genet. 2009;54(1):15-39.

2. Shi H, Zhong H, Peng Y, Dong Y-L, Qi X-B, Zhang $\mathrm{F}$, et al. Y chromosome evidence of earliest modern human settlement in East Asia and multiple origins of Tibetan and Japanese populations. BMC Biol. 2008;6:45.

3. Zhang F, Su B, Zhang Y, Jin L. Genetic studies of human diversity in East Asia. Philos Trans R Soc Lond B Biol Sci. 2007;362(1482):987-
95.

4. Kong QP, Sun C, Wang HW, Zhao M, Wang WZ, Zhong L, et al. Large-Scale mtDNA screening reveals a surprising matrilineal complexity in East Asia and Its implications to the peopling of the region. Mol Biol Evol. 2011;28(1):513-22.

5. Shiina T, Suzuki S, Ozaki Y, Taira H, Kikkawa E, Shigenari A, et al. Super high resolution for single molecule-sequence-based typing of classical HLA loci at the 8-digit level using next generation sequencers. Tissue Antigens. 2012;80(4):305-16.

6. Sanchez-Mazas A, Meyer D. The relevance of HLA sequencing in population genetics studies. J Immunol Res. 2014; 2014:971818.

7. Yuliwulandari R, Kashiwase K, Nakajima H, Uddin J, Susmiarsih TP, Sofro ASM, et al. Polymorphisms of HLA genes in Western Javanese (Indonesia): close affinities to Southeast Asian populations. Tissue Antigens. 2009;73(1):46-53.

8. Stoneking M, Delfin F. The human genetic history of East Asia: weaving a complex tapestry. Curr Biol. 2010;20(4):R188-93.

9. Chin YM, Mushiroda T, Takahashi A, Kubo M, Krishnan G, Yap LF, et al. HLA-A SNPs and amino acid variants are associated with nasopharyngeal carcinoma in Malaysian Chinese. Int J Cancer. 2015;136(3):678-87.

10. Wang R, Hu Y, Yindom LM, Huang L, Wu R, Wang D, et al. Association analysis between HLA-A, -B, -C, -DRB1, and -DQB1 with nasopharyngeal carcinoma among a Han population in Northwestern China. Hum Immunol. 2014;75(3):197-202.

11. Wee JTS, Ha TC, Loong SLE, Qian CN. Is nasopharyngeal cancer really a "Cantonese cancer”? Chin J Cancer. 2010;29(5):517-26.

12. Guo XC, Scott K, Liu Y, Dean M, David V, Nelson GW, et al. Genetic factors leading to chronic Epstein-Barr virus infection and nasopharyngeal carcinoma in South East China: study design, methods and feasibility. Hum Genomics. 2006;2(6):365-75.

13. Adham M, Kurniawan AN, Muhtadi AI, Roezin A, Hermani B, Gondhowiardjo S, et al. Nasopharyngeal carcinoma in indonesia: Epidemiology, incidence, signs, and symptoms at presentation. Chin J Cancer. 2012;31(4):185-96.

14. Simons MJ. The origin of genetic risk for nasopharyngeal carcinoma: a commentary 
on: is nasopharyngeal cancer really a "Cantonese cancer"? Chin J Cancer. 2010;29(5):527-37.

15. Bei JX, Li Y, Jia WH, Feng BJ, Zhou G, Chen LZ, et al. A genome-wide association study of nasopharyngeal carcinoma identifies three new susceptibility loci. Nat Genet. 2010;42(7):599-603.

16. Tang M, Lautenberger JA, Gao X, Sezgin E, Hendrickson SL, Troyer JL, et al. The principal genetic determinants for nasopharyngeal carcinoma in China involve the HLA class I antigen recognition groove. PLoS Genet. 2012;8(11):e1003103.

17. Tang M, Zeng Y, Poisson A, Marti D, Guan L, Zheng Y, et al. Haplotype-dependent HLA susceptibility to nasopharyngeal carcinoma in a Southern Chinese population. Genes Immun. 2010;11(4):334-42.

18. Hildesheim A, Apple RJ, Chen C, Wang SS, Klitz W, Mack SJ, et al. Association of HLA class I and II alleles and extended haplotypes with nasopharyngeal carcinoma in Taiwan. $\mathrm{J}$ Natl Cancer Inst. 2002;94(23):1780-9.

19. Au WY, Hawkins BR, Chan EY, Lie AK, Kung AW, Liang R, et al. Association of the HLA A2-B46-DR9 haplotype with autoimmune thyroid dysfunction after bone marrow transplantation in Chinese patients. $\mathrm{Br} \mathrm{J}$ Haematol. 2001;115(3):660-3.

20. Hoa B, Hang N, Kashiwase K, Al E. HLA-A, -B, -C, -DRB1 and -DQB1 alleles and haplotypes in the Kinh population in Vietnam. Tissue Antigens. 2008;71(2):127-34.

21. Shi L, Xu SB, Ohashi J, Sun H, Yu JK, Huang XQ, et al. HLA-A, HLA-B, and HLA-DRB1 alleles and haplotypes in Naxi and Han populations in southwestern China (Yunnan province). Tissue Antigens. 2006;67(1):3844.

22. Ogata S, Shi L, Matsushita M, Yu L, Huang XQ, Shi L, et al. Polymorphisms of human leucocyte antigen genes in Maonan people in China. Tissue Antigens. 2007;69(2):154-60.

23. Shi L, Yao YF, Shi L, Matsushita M, Yu L, Lin QK, et al. HLA alleles and haplotypes distribution in Dai population in Yunnan province, Southwest China. Tissue Antigens. 2010;75(2):159-65.

24. Shi L, Shi L, Yao YF, Matsushita M, Yu1 L, Huang XQ, et al. Genetic link among Hani, Bulang and other Southeast Asian populations: evidence from HLA -A, -B, -C,
-DRB1 genes and haplotypes distribution. Int J Immunogenet. 2010;37(6):467-75.

25. Shi L, Ogata S, Yu JK, Ohashi J, Yu L, Shi L, et al. Distribution of HLA alleles and haplotypes in Jinuo and Wa populations in Southwest China. Hum Immunol. 2008;69(1):58-65.

26. Tamura K, Dudley J, Nei M, Kumar S. MEGA4: molecular evolutionary genetics analysis (MEGA) software version 4.0. Mol Biol Evol. 2007;24(8):1596-9.

27. Wang Q, Zhou JQ, Zhou LM, Chen ZY, Fang $\mathrm{ZY}$, Chen SD, et al. Association between HLA-B* 1502 allele and carbamazepineinduced severe cutaneous adverse reactions in Han people of southern China mainland. Seizure. 2011;20(6):446-8.

28. Zhang FR, Liu H, Irwanto A, Fu XA, Li Y, Yu GQ, et al. HLA-B*13:01 and the dapsone hypersensitivity syndrome. N Engl J Med. 2013;369:1620-8.

29. Yang F, Gu B, Zhang L, Xuan J, Luo H, Zhou P, et al. HLA-B* ${ }^{*} 3: 01$ is associated with salazosulfapyridine-induced drug rash with eosinophilia and systemic symptoms in Chinese Han population. Pharmacogenomics. 2014;15(11):1461-9.

30. Wangsomboonsiri W, Mahasirimongkol S, Chantarangsu S, Kiertiburanakul S, Charoenyingwattana A, Komindr S, et al. Association between HLA-B*4001 and lipodystrophy among HIV-infected patients from Thailand who received a stavudinecontaining antiretroviral regimen. Clin Infect Dis. 2010;50(4):597-604.

31. Shimane K, Kochi Y, Suzuki A, Okada $\mathrm{Y}$, Ishii $\mathrm{T}$, Horita $\mathrm{T}$, et al. An association analysis of HLA-DRB1 with systemic lupus erythematosus and rheumatoid arthritis in a Japanese population: effects of *09:01 allele on disease phenotypes. Rheumatology (Oxford). 2013;52(7):1172-82.

32. Chen PL, Fann CSJ, Chu C-C, Chang CC, Chang SW, Hsieh HY, et al. Comprehensive genotyping in two homogeneous Graves' disease samples reveals major and novel HLA association alleles. PLoS One. 2011;6(1):e16635.

33. Liu B, Xiong L, Tian C, Zhou Q, Zhong Y, Li A, et al. HLA-DRB1*12:02:01 plays a protective role against coronary artery disease in women of southern Han Chinese descent. Hum Immunol. 2012;73(1):122-6.

34. He D, Wang J, Yi L, Guo X, Guo S, Guo G, 
et al. Association of the HLA-DRB1 with scleroderma in Chinese population. PLoS

One. 2014;9(9):e106939. 